\section{HONORARY CURATOR RETIRES}

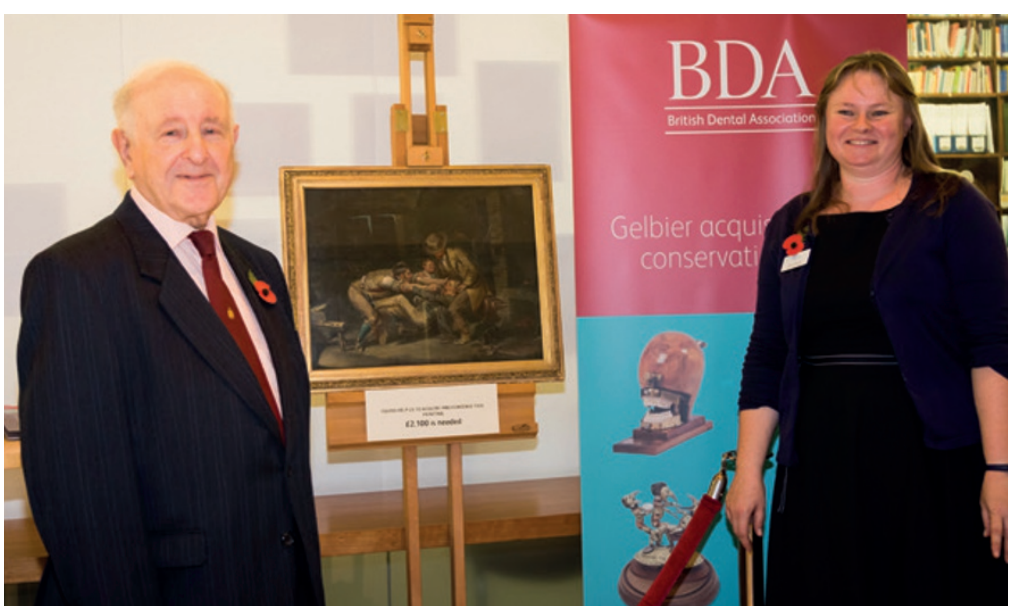

Professor Stanley Gelbier (left) with Rachel Bairsto (right)

Friends and colleagues representProfessor Stanley Gelbier after 33 years as Deputy and Honorary Curator of the tribution made by Professor Stanley mous contribution to dental history of the BDA to mark the museum's eightieth birthday. aims to help to raise money to purfor the enjoyment of future generations. Rachel Bairsto, Head of Museum evening by launching this fund. ing all areas of his career gathered at the BDA to mark the retirement of BDA Museum.

The museum celebrated the conGelbier at an event on 4 November, where BDA President Nairn Wilson spoke of Professor Gelbier's numerous honours and awards and enorbefore presenting Professor Gelbier with a specially commissioned print

The museum also launched the Gelbier Acquisition and Conservation Fund in his honour. The new fund chase new and historically important acquisitions for the museum collection Services, said: "We are thrilled to be able to honour Stanley and his contribution to the BDA Museum this

Your donations will ensure that the museum can acquire important works and conserve them. We are very sad to see Stanley go but wish him all the best in his well-earned retirement.'

Guests at the event enjoyed the opportunity to test the museum's new audioguide. Visitors can now explore the museum collection by listening to extracts from interviews collected by the John McLean archive: a living history of dentistry. Whilst looking at bone handled toothbrushes visitors can listen to Robin Addis talking about the manufacture of toothbrushes, dental technicians talking about making vulcanite dentures in the 1950s and many more fascinating, entertaining and revealing insights.

Also on display at the event was a rare Victorian oil painting of a blacksmith dental extraction scene which the museum would like to acquire to complement its existing art collection. The museum needs $£ 2,300$ (including conservation) to acquire this work.

To help the museum acquire the work, please visit www.bda.org/ gelbierfund.

\section{AGM NOTICES}

The 130th Annual General Meeting of the British Dental Association (Southern Counties Branch) will he held on Thursday 28 April, 2016 at 6.00 pm at the Lennox Room, Goodwood Hotel, Chichester, P018 0QB. Apologies can be forwarded to John Strevens at str1jas@hotmail.com

The Annual General Meeting of the Middlesex and Hertfordshire Branch of The British Dental Association will be held on Thursday 11 February, 2016 at the Holiday Inn, Elstree, WD6 5PU at 7.00 pm.

All members of the branch are welcome to attend and vote. Apologies on 01992460467 or $01707332924 / 394613$.

\section{SOCIAL SCIENTISTS NEEDED TO SOLVE THE PROBLEM OF ANTIBIOTIC OVERUSE}

'The rise of resistance to antibiotics (anti-microbial resistance, AMR) is largely a consequence of human action, and is as much a societal problem as a technological one.'

Those are the words of Dr Helen Lambert, AMR Research Champion for the Economic and Social Research Council (ESRC).

The solution to AMR (when bacteria and other diseasecausing organisms become resistant to drug treatment) is widely thought to lie in the development of new antibiotics and diagnostic tests.

However, on beginning the role of Champion - a position set up by the ESRC as part of a £150,000 grant - Dr Lambert said social science research 'is as important as laboratory research in tackling this global health problem'.

'Social organisation is just as important as what happens in the laboratory. We need to find answers to questions such as why antibiotics are often overused, how pharmaceutical supply chains and the organisation of healthcare affect access to antibiotics, or what part farming practices might play in AMR transmission.'

She added: 'In this role, I aim to engage with a broad range of social scientists - from economists and psychologists to anthropologists and geographers - in undertaking research relevant to AMR, as well as highlighting the need for social science evidence that will help improve our understanding and lead to new ways of dealing with the threat of infections caused by antibiotic-resistant bacteria.'

Dr Lambert, who is a Reader in Medical Anthropology from the University of Bristol's School of Social and Community Medicine, said she was delighted to lead the project working alongside her colleague Dr Christie Cabral.

Over the coming year Dr Lambert and colleagues will be organising a range of activities to engage researchers and highlight relevant research.

Naomi Beaumont, ESRC Senior Research Portfolio Manager - Health and Human Behaviour, said: 'AMR has been described as a major challenge of our times, with available drugs becoming ineffective in treating a growing number of infections, as bacteria and other pathogens evolve to become resistant to them.

'We know that many of the effects of this phenomenon are social, as are the potential solutions - for example, the impact that global migration has on disease transmission, the influence of global and national pharmaceutical markets on consumption patterns, and the impact of intensive farming practices on the consumption of antibiotics in animals.

'The role of the Champion will therefore be to highlight the relevance of social science to the challenge of AMR and to build interest among a wide range of social scientists - including those who don't currently actively research in this area.' 